\title{
The Debates on Human Nature and Political Governance in Ancient China: Mencius, Xunzi and Han Feizi
}

\author{
Tingchun Ngai \\ Department of Public Policy, City University of Hong Kong, Hong Kong, China \\ Email: andyngai0104@gmail.com
}

How to cite this paper: Ngai, T.C. (2019) The Debates on Human Nature and Political Governance in Ancient China: Mencius, Xunzi and Han Feizi. Open Access Library Journal, 6: e5369.

https://doi.org/10.4236/oalib.1105369

Received: April 3, 2019

Accepted: April 26, 2019

Published: April 29, 2019

Copyright $\odot 2019$ by author(s) and Open Access Library Inc.

This work is licensed under the Creative Commons Attribution International License (CC BY 4.0).

http://creativecommons.org/licenses/by/4.0/

\section{(c) (i) Open Access}

\begin{abstract}
Researches of ancient Chinese philosophy have become popular within the academic field nowadays, especially in the Western world. The study of ancient Chinese philosophers, indeed, provided a critical insight for scholars to understand Chinese philosophy and history. This paper examines three renowned ancient Chinese philosophers, namely Mencius, Xunzi and Han Feizi, which is conducive to outline the evolution of the discussion of the ideas of human nature and political governance across the warring-state period. By studying their philosophical origins and perspectives, this paper re-examines the ancient classical compositions and existing analyses and contributes to the academic domain in threefold. It provided a comprehensive elucidation of the above philosophers' arguments, both origins and core values, compared and contrasted the philosophical ideas among them, as well as illuminated the misconceptions or misinterpretations on current scholastic literatures.
\end{abstract}

\section{Subject Areas}

Philosophy

\section{Keywords}

Mencius, Xunzi, Han Feizi, Chinese History, Chinese Philosophy

\section{Introduction}

The debate on humans' nature is an important political philosophical topic during the pre-Qin period. Three notable philosophers, namely Mencius, Xunzi and Han Feizi, expressed their views towards humans' nature as well as its correlations with society and political governance. Given the timeline of Ancient Chinese history, from Mencius to Han Feizi, the latter two philosophers developed 
their philosophical arguments on the anterior ones, thus their perspectives were exceptionally related to each other. This paper examined the origins and offered interpretations of philosophical ideas on human nature among the three pre-Qin philosophers. Moreover, it compares and contrasts the three above philosopher' pivotal political ideas and their origins. This is crucial to offer vital insights for why Legalism (Fajia) could prevail and Confucianism did not welcome among the state governors within the warring states period. Besides, it elucidated the misconception of previous works on Xunzi's and Han Feizi's philosophy. ${ }^{1}$

\section{Mencius: Good Nature and Benevolent Ruling}

\subsection{Mencius's Philosophical Origin}

Mencius born amid the warring-state period. His educator is a student of Zisi, while Zisi is the grandson of Confucius. Therefore, the ideas of Mencius are extraordinarily swayed by the philosophy of Confucius and Zisi [1]. Confucius briefly referenced the human nature, but had not discussed it in depth [2]. According to $<<$ Yong Ye $>>$, Confucius regarded uprightness as the nature of human-being ${ }^{2}$. Moreover, Confucius believe all humans share similar inborn nature, however, the socialization of each individuals would be significant distinctive $^{3}$. Besides, Zisi regards benevolence (ren) as the inherent human nature ${ }^{4}$. He proposes that the practice of benevolent deeds is the manifestation of human nature. Therefore, some points can be drawn from the two thinker's views. Human nature should be regarded as good and it can be altered by external environment. Additionally, the way to practice good virtues is to cultivate ourselves. However, neither Confucius's and Zisi's views on human nature are vague, thus Mencius is the primary Chinese philosopher who unequivocally proposed his views or theories on the discourses of human's nature. By referring to the publications about Mencius, it can be observed that his idea of "original righteousness of human nature" shared the attributes of Confucius's and Zisi's viewpoints.

\subsection{Mencius's Theory of Original Goodness of Human Nature}

Mencius proposed that human possessed inborn virtue by utilizing a story to de-

\footnotetext{
${ }^{1}$ In order to facilitate discussions within this paper, both first-hand and second-hand data were massively cited in the content as well as the footnotes. The first-hand data mainly involves the English translations of the original publications of Mencius, Xunzi and Han Feizi. With regards to the original publications of Mencius, this paper employed the translation from sinologist Lionel Giles. In terms of Xunzi's original publications, this paper cited the translations from Eric L. Hutton, an associate professor In the Department of Philosophy of University of Utah. This essay also included the book of W. K. Liao as the English sources for Han Feizi's original publications. Besides, the book of the Doctrine of the Mean and The Analects also cited in this essay, thus, the translations of A. Charles Muller, a professor of University of Tokyo, and Patrick Edwin Moran, a Doctor of Philosophy in Wake Forest University, are used respectively. Moreover, abundant works from scholars, historians and philosophers were adopted for discussion. This paper used some of the works to support the interpretations of the original publications of the above three philosophers. This paper would provide a critical view towards some existing scholastic works.

${ }^{2}$ The Master said: "People are straightforward at birth." [3]

${ }^{3}$ The Master said: "People are similar by nature, but through habituation become quite different from each other" [3].

"'The xing (human nature) is what Heaven has called into existence within us through its mandate. To follow out this xing is called one's dao (way, course, process). To correct (i.e., cultivate) the dao that one takes in life is called the process of education" [4].
} 
lineate this idea: "When a man saw an infant almost fall into the well, he immediately ran to help and rescue the body". He analysed the action of that man and pinpointed he, as with every human-beings, would not bear to see the sufferings of others. While his action to help is not based on any calculations or contemplations, such as trying to please the infant's parents or establishing a good reputation within the community, rather it is simply a reflection of innate virtue ${ }^{6}$. Therefore, humans are inborn virtue. Mencius then further proposed his theory of "Four Cardinal Virtues", which argued that "benevolence" (ren 仁), “ritual propriety” ( $l i$ 義), “rightness” ( $y i$ 禮), and “wisdom” ( $z h i$ 智) are the components of moral virtues. In addition, he mentioned the four basic human sentiments: "feeling of compassion", "feeling of shame", "feeling of consideration for others" and "sense of right and wrong" are the starting point of "humaneness", "ritual propriety", "rightness", and "wisdom" respectively". It is crucial to note that Mencius believes the four fundamental human sentiments are vital to distinguish human-being and other species as well as they are inalienable with humans' nature as we possess four appendages ${ }^{8}$. Since Mencius believed humans are characteristically good, what they need is to self-cultivate their innate virtues?

Besides, Mencius's idea of human nature can also be concluded from the debates between him and Gaozi. Gaozi first argued against Mencius's idea of man's nature is intrinsically good. He used willow and bowls as an analogy, which people utilize willow to produce bowls. If willow is equals to human nature and bowls are viewed as benevolence and righteousness, then Mencius is just treating raw materials as products. However, Mencius replied when we used willow to yield bowls, we would damage the nature of willow ${ }^{10}$. If we, according to Gaozi's logic, would can to a conclusion that people need to injure humanity in order to practice benevolence and righteousness, which is completely preposterous ${ }^{11}$. Gaozi then employed another analogy by saying that human nature is just like water currents, which it does not regarded good or bad as water current can flow 5"Mencius said: All men have a certain sympathy towards their fellows... What I mean by this feeling of sympathy which all men possess is this: If anyone were to see a child falling into a well, he would have a feeling of horror and pity...” [5].

"'[he would have a feeling of horror and pity,] not because he happened to be an intimate friend of the child's parents, nor because he sought the approbation of his neighbours and friends, nor yet because he feared to be thought inhumane." [5].

7"The feeling of compassion is the origin of benevolence; the feeling of shame is the origin of righteousness; the feeling of consideration for others is the origin of good manners; the feeling of right and wrong is the origin of wisdom." [5].

"The presence of these four elements in man is as natural to him as the possession of his four limbs" [5].

9"Mencius said: He who gets to the bottom of his mind comes to knows his own nature; knowing his own nature, he also knows God. Preserving one's mind in its integrity and nourishing one's nature is the way to serve God. To practice self-cultivation and await whatever may betide, indifferent whether life be long or short: that is the way to establish one' destiny." [5].

${ }^{10}$ “The philosopher Kao said: Man's nature may be likened to a willow tree; righteousness, to a cup or bowl. Making a man's nature righteous and good is like making cups and bowls put of the wood of a willow tree." [5].

11 "Mencius replied: Can you make cups and bowls without interfering with the nature of the willow? No, you can only do so by doing violence to its nature. That being the case, would you say that men can only be made righteous and good by doing violence to their nature? Your argument would then necessarily lead man kind to regard goodness and righteousness as a misfortune!" [5]. 
towards the east or the west ${ }^{12}$. Yet, Mencius affirmed that water currents can only flow to the lower area and it is just similar as human nature that inborn virtue $^{13}$. Regardless of striking it upwards, it may leap up a little, but it still flow downwards ${ }^{14}$. Thus, human are internally possess good virtue, but the society caused them act against the moral principles in certain social contexts.

\subsection{Human Nature is Transformable}

Ironically, when the time that Mencius's expressed his musings on human nature as inborn virtuous, China was experiencing the warring-state period. It is not rare to see rulers act against the moral principles, such as fighting wars or practice tyrannical governance, and the ordinary citizens lived under extraordinary awful social conditions and they also violate moral norms for survival. In this manner, major doubt on Mencius's idea is if humans' nature is inborn virtuous, then why would people act against the moral principles within the society? Mencius argues there are two reasons that make people behave badly [6] [7]. Firstly, the individuals do not uphold his/her inward virtues. He believes that people would lose their virtues if they ignore them ${ }^{15}$. People would not automatically act ethically even though we possess the four basic human sentiments of good virtues and what we need is to cultivate our inner self. Moreover, Mencius also mentioned the external society would change people's inner moral virtues. He refers the idea to the story of a mountain: "There is a mountain which is full of trees and appear to be emerald green (An analogy of humans' nature is initially good), but people who live nearby constantly cropping the wood from the hill and the mountain become barren place (akin to the temptations of the society made us undermine our moral virtues gradually). Therefore, people who are not live nearby would have a misconception that the mountain was originally barren (similar to people who behave badly in the society are accused to be inherently bad)." ${ }^{16}$ Hence, it is argued that one's nature is inborn virtuous; how-

${ }^{12}$ The philosopher Kao said: Man' nature is like a current of water: deflected in an easterly direction, it will flow to the east; deflected in a westerly direction, it will flow to the west. And just as water has no predilection either for east or west, so man's nature is not predisposed either good or evil." [5].

13 "Mencius replied: It is true that water has no predilection for east or west, but will it flow equally well up or down? Human nature is disposed towards goodness just as water flows downwards. There is no water but flows down, and no men but show this tendency of good." [5].

14"Now, if water is slashed up, it can be made to go right over your head; by forcing it along, it can be made to go uphill. But how can that be termed its natural bent? It is some external forces that cause it to do so. And likewise, if men are made to do what is not good, their nature is being distorted in a similar way." [5].

15 "Benevolence, righteousness, propriety and wisdom are not instilled into us from without-they are part of our very being. Only we give them no thought. Hence the saying: 'You can have them for the seeking, or lose them through neglect." [5].

16"Mencius said: Beautiful once were the trees on Mount Niu: but, standing on the outskirts of a great capital, they were ruthlessly lopped with axe and bill: how could their beauty then endure? Quickened, however, by the alternation of day and night, and fed by the rains and the dew, some shoots again put forth. But cows and goats came and browsed upon them, and so the mountain became denuded as you see it now; and seeing its denudation, people imagine that no timber ever grew upon it. Yet such was assuredly not its real nature. So with the natural endowment of man: how can it be devoid of the feeling of benevolence or the sense of what is right? But these good feelings are shed in the same way as trees are felled by the axe. If they are cut down day after day, how can the beauty of the mind endure? Though quickened by the alteration of day and night, the moral judgements which are intimately associated with the mind of man tend to grow weaker after the breath of dawn, and as the result of the day's destructive work atrophy sets in." $[5]$. 
ever, it need to be cultivated by persons themselves. Moreover, it exemplified that the human nature is alterable.

\section{4. "Kingly Way" and Benevolent Governance}

Mencius's theory of original goodness of human nature established a foundation for his idea of political governance, which is rule by Kingly Way ${ }^{17}$. A ruler should possess moral character and employ moral goddesses as means of governance. Therefore, Mencius accentuated rulers' has two political missions: self-cultivation and inspiring people towards moral goodness [8] [9]. Since Mencius believes that human nature is inherently good, it is needed to self-cultivate them by practice moral behaviours in daily life in order to embody the goodness in yourself. While the rulers should also need to "extend" his moral goodness towards the people, they should practice benevolence ruling to educate citizens with good virtues and use himself as a moral role to exemplify rituals [10]. For instance, rulers should provide aid to people when there are starvation, which is a practice of benevolence (ren), but not let people struggle by themselves. Since the kings implement a benevolent ruling and maintain a good social environment for the people, the citizen would have more leisure time for self-cultivating their innate goodness as well ${ }^{18}$. Finally, a moral social order would establishe as long as the rule by rituals is actualized.

\section{Xunzi: Evil Nature and Rule by Rituals and Laws}

\subsection{Xunzi's Origins of his Ideas of Human Nature}

Notwithstanding Mencius and Xunzi belong to the school of the Confucianism, numerous scholars regards them as two isolated factions [11] [12] [13]. Many ideas of Xunzi opposed to Mencius's philosophies, even Xunzi himself has criticized Mencius's thoughts a lot. Savants examined the origins of Xunzi's thoughts and argued he has generated many ideas from the Hundred Schools of Thought, such as the "Xujing" from Laozi and "benevolence" (ren), "ritual propriety" ( $I i)$, and "rightness" ( $y i)$ from Confucius. This paper accentuated on his idea of human nature and argued the Jixia Academy has a significant impact to the formation of Xunzi's view of human nature. Many papers endeavoured to comprehend the ideologies of Jixia Academy by examining its publications, for instance

《Guanzi》 and 《Lüshi Chunqiu》. While Xunzi was one of the academicians in Jixia Academy for several decades, he is able to learn different schools of thoughts and formulate his own ideologies. 《Guanzi》 defines human nature is self-interested might likely to impact Xunzi to define human nature is inborn malevolence [14]. Besides, many papers that examine 《Lüshi Chunqiu》found that it defines human nature as "lust", which totally identical with Xunzi's defi-

17"Making it possible for them [people] to nourish their lives, bury their dead, and be without rancor is the beginning of the Kingly Way." [5].

${ }^{18}$ "If your Majesty will confer benevolent rule on the people, lighten punishments, reduce taxation, encourage deep ploughing and the use of the hoe; if in their spare time the able-bodied make an effort to be filial, fraternal, conscientious and faithful, rendering service to their fathers and elder brothers in the home, and out of it, to their seniors and superiors" [5]. 
nition of human nature as people's original desires [15] [16]. The publication of 《Lüshi Chunqiu》has a high opportunity to mirrors Xunzi's idea at the time that he stayed in Jixia Academy. Accordingly, Xunzi did not accept Confucius's conviction of goodness is rooted within human themselves as well as Mencius's "theory of original goodness of human nature".

\subsection{Xunzi: Human Nature is Innate Fiendish}

Xunzi has learned about Mencius's idea on human nature and thoroughly disagree with it. Within one of his articles, he argued against Mencius's arguments. Mencius argues that people's nature is good as they can learn to be good. However, from Xunzi's perspectives, "nature" means something that are inherent when we were born, such as the abilities of hearing and watching. Therefore, if moral norms and principles can be acquired, how can they be defined as "nature" ? ${ }^{19}$ Moreover, Xunzi disagrees Mencius's of humans are inherently good and the reason that they act against moral principles is they have lost their inner nature. Yet, what Xunzi observed is people need to act against their lusts when they practice moral behaviours, for example people would wait for the elderlies to eat first even though they were hungry, it regards as a kind of "politeness" 20 . Thus, if Mencius is right, the human nature and their moral actions should not against each other but mutually benefit. The last rebuttals referred to Mencius's core idea of human are inherently virtue. Xunzi casted doubt on the assertion. He doubted that if humans are truly, as Mencius mentioned, are inborn virtues, why people need to be educated to be good? ${ }^{21}$

The core beliefs of Xunzi's human nature drew from his definitions of "nature" and "deliberate efforts". He argues there is contrast between them (性偽之 分) $)^{22}$. "Nature" is something that is characteristic, which cannot be learned or

19“Mencius says: When people engage in learning, this manifests the goodness of their nature. I [Xunzi] say: This is not so. This is a case of not attaining knowledge of people's nature and of not inspecting clearly the division between people's nature and their deliberate efforts. In every case, the nature of a thing is accomplishment of Heaven. It cannot be learned. It cannot be worked at. Ritual and yi are what the sage produces They are things that people become capable of through learning, things that are achieved through working at them. Those things in people which cannot be learned and cannot be worked at are called their "nature". Those things in people which they become capable of trough learning and which they achieve through working at them are called their "deliberate efforts" This is the division between nature and deliberate efforts." [17]

20"Mencius says: people's nature is good, but they all wind up losing their nature and original state. I [Xunzi] say: if it is like this, then he is simply mistaken. People's nature is such that they are born and then depart from their original simplicity, depart from their original material; they are sure to lose them. Looking at it in this way, it is clear that people's nature is bad. The so-called goodness of people's nature would mean for one not to depart from one's original simplicity and instead beautify it, not to depart from one's original material and instead make use of it." [17]

${ }^{21}$ "Mencius says: people's nature is good. I [Xunzi] say: this is not so. In every case, both in ancient times and in the present, what everyone under Heaven calls good is being correct, ordered, peaceful, and controlled. What they call bad is being deviant, dangerous, unruly and chaotic. This is the division between good and bad. Now does he really think that people' nature is originally correct, ordered, peaceful, and controlled? Then what use would there be for sage kings? What use for ritual and yi? Even though there might exist sage kings and ritual and yi, whatever could these add to its correct, ordered, peaceful, and controlled? Now that is not the case, because people's nature is bad, people were deviant, dangerous and not correct, unruly, chaotic, and not well-ordered." [17]

22"Those things in people which cannot be learned and cannot be worked at are called their "nature". Those things in people which they become capable of trough learning and which they achieve through working at them are called their "deliberate efforts" This is the division between nature and deliberate efforts." [17] 
pretended and those are not inborn but procured should regard as "deliberate efforts", for instance moral virtues and knowledge. From his perspectives of human nature, he regards human's original lusts as "nature" and moral principle as "deliberate efforts". When people are hungry, they want to eat; when people are exhausted, they want to rest; When people suffer from cold, they wish to be warmed, these natural or original human desires are "nature" in Xunzi's mind. While it is harmful to the society if we do not confined these original human lusts as human desires are boundless. In order to satisfied their demands or wants, people possess malice to harm others. It alludes to what Xunzi's idea of man's nature is inherently bad because it involves fondness for profit and hate. Once these kinds of evil inner nature are being practiced by people and extend to the whole society, the society would result in turmoil ${ }^{23}$. Therefore, humans inborn with greed, envy and lust [18]. Stealing and robberies occurred would occurred as people's avarice need to be fulfilled; Usurpations and loss of loyalty would appear as people's practice according to envy; lascivious society would be resulted as people need to satisfy their lusts. Hence, Xunzi concluded his theory on human nature as innate evil and their goodness are deliberate endeavours.

\subsection{Society: A Source of Moral Principles}

Akin to Mencius, people casted doubt on why people practice moral customs if they are inherently bad as Xunzi mentioned. The Xunzi's response is the society act as a source for people to be morally educated. Sages, who create the moral tenets, uphold a same view with Xunzi's that they need to limit human innate bad nature by moral virtues. Similar to potters acquired to produce bowl, the sages realized human nature is innate evil and people's ability to learn in order to change their badness. Thus, the moral principles or rules are set up by sages to educated people to practice good virtues, and laws are made to restrict the expansion of bad human nature. Also, Xunzi believed learning do distinguish between bad and good. As he argues all human-beings, no matter a benevolent governor or a tyrant, share the same bad innate nature, but people can learn to be good and practice benevolence to change their badness. This is the reasons why we admire and respect good rulers, such as Emperor Yao (堯) and Shun (舜), are they can alter their innate malignancy (化性) and establishing good personnel and practice (起偽) ${ }^{24}$. Likewise, people should also learn be good by practicing moral rituals and understanding the moral thoughts of the sages, then

\footnotetext{
23"Now people's nature is such that they are born with a fondness for profit in them. If they follow along with this, the struggles and contention will arise, and yielding and deference will perish therein. They are born with feelings of hate and dislike in the. If they follow along with these, then cruelly and villainy will arise, and loyalty and trust-worthiness will perish therein. They are born with desires of the eyes and ears, a fondness of for beautiful sights and sounds. If they follow along with these, then lasciviousness and chaos will arise, and ritual and yi, proper form and order, will perish therein." [17]

24"Everything that one values in Yao and Shun and the gentleman is due to the fact that they were able to transform their nature and to establish deliberate efforts. In establishing deliberate effort, they produced ritual and yi... Anyone on the streets can become a Yu. How do I mean this? I say: that by which Yu was Yu was because he was ren, yi, lawful and correct. Thus, ren, yi, lawful and correctness have patterns that can be known and can be practiced. However, people on the streets all have the material for knowing ren, yi, lawfulness and correctness. Thus, it is clear that they can become a Yu." [17]
} 
everyone would has an opportunity to be as good as Yao and Shun.

\subsection{Political Rule: Rituals and Laws}

Xunzi's philosophies of human nature also become his fundamental bedrocks of his theory of rule by rituals (li) and laws [19]. On one hand, Xunzi suggested that $l i$, such as moral principles and rules should be uphold by rules as well as to use them to educate people to act according to moral goodness. The purpose of rule by $l i$ is crucial to establish a social order, which relying on the "unwritten" norms to regulate people practice benevolent acts [20] [21]. This idea actually partly inherited from Confucius's thoughts of rule by virtues (li ji), however, Xunzi tend to highlight its social function that ritual propriety served in the realm of governance. On the other hand, Xunzi also asserted laws are needed. Laws, in Xunzi's idea, served the function to stated or practice harsh punishments to restrict human from violating moral principles. It should be regards as last resorts when $l i$ does not function well in the society. Yet, this paper argues that rule by $l i$ prior than rule by laws are not sharing an equivalent status in Xunzi's world. He thinks the former is prior than the latter. Law is the derivation of moral norms $\mathrm{s}^{25}$, its establishment must follow the principles of rituals, hence, it can assure the moral order is well operated within the society.

\section{Han Feizi: A Natural View and Rule by Laws}

\subsection{Han Feizi's Philosophical Origins on Human Instinct}

Han Feizi is the originator of the Legalism, his philosophiesal together significantly influenced by the "legalist ancestors", such as Shen Dao, Guanzi and Shang Yang [22]. Shen Dao believes humans are self-interested individuals [23]; Guanzi pinpointed humans would pursue benefits and avoid dangers [24]; Shang Yang argues humans are detestable [25]. Their views moulded the extent of Han Feizi's thoughts of human instinct [26] [27]. Furthermore, Han Feizi, as a student of Xunzi, learned from Xunzi's ideas on human nature. He, follows his instructor, observed people through to their origins of natural desires and found that people only act according to their natural desires. Scholars argued Han Feizi, as the student of Xunzi, completely inherit his teacher's ideas of evil human nature [28] [29]. However, the paper argues this is a misconception. One domain that Han Feizi distinguished with Xunzi, is that he believes human nature cannot be altered by moral education. Thus, Han Feizi abolished rituals and turn to concentrates on laws and punishments. Another savant that impact Han Feizi's thoughts is Laozi. He is an expert of 《Tao TeChing》, that many historians attested that Laozi's concept of "adapting and conforming to nature" is absorbed by Han Feizi [30]. This is also the reason why he, unlike Mencius and Xunzi, considers human nature cannot be altered or need to be changed.

Beyond his educational background has impact on his ideologies, the social

25"In the reverence and refinement of ritual, the balance and harmony of music, the broad content of the Odes (the repository of balanced sound) and Documents (the record of government affairs), the subtleties of the Spring and Autumn Annals, all things between Heaven and Earth are complete." [17]. 
context of his period also contributed his formation of thoughts [31] [32]. In light of his observations to the society, he proposed an extremely critical view towards human relations. He found that parents would kill their daughters as cost-benefit calculations draw from traditional prejudice on female under Chinese patriarchal society. Moreover, Han Feizi also found that there is no loyalty between spouses and king and officials, thus, cheatings and usurpations are not rare at that time. The social background of Han Feizi's period influences his idea towards human relationship as well as human nature.

\subsection{Han Feizi Core Ideas of Human Nature}

Han Feizi characterizes human nature as "pursue interests and avoid dangers"26 (趨吉避凶) and “cherish self-seeking”27 (挾自為心). This view is similar to Xunzi that human act according to their desires. Unlike Mencius who advocates human-beings are heterogeneous form animals as we possess moral virtues, Han Feizi regards humans are almost identical to creatures [33]. Just like animals that behave based on instinct, basic impulses and emotions, human also act according to self-seeking and disregards moral norms and principles. This definition supported by Han Feizi from his perceptions of humans relationship mentioned previously. For example, Han Feizi argued the reason why usurpations occurred as people are desperate for the thrones (pursue political power as interest) and the reason why people kill their female infants (avoid economic loss for cultivating a girl when they compare to a male's economic production capacity). Yet, a vital point to be mentioned is Han Feizi does not evaluate human nature as inherently good as Mencius or as innately bad as Xunzi [34] [35]. What he did is provide a definition on human nature based on his understandings and observations. Hence, in his view, the nature of people is induced by the original needs of human beings and they are the natural instinct of human beings, which unchangeable or dispensable to change.

\subsection{Society: An Authority to Compel Benevolent Practice}

In terms of external society, Han Feizi shared a similar view with Xunzi that society as a force of moral virtues. As mentioned above, Xunzi regards society as a spot to educated citizen to be good. However, Han Feizi hold a marginally heterogeneous view that he deems society is an external force that compels humans to act morally ${ }^{28}$. Whether moral actions originate from people's heart, Han Feizi holds a negative view. Therefore, Han Feizi does not deem moral education is necessary. Since human nature is unchangeable, it is no point to focus on educating people with moral virtues. Moreover, Han Feizi absorbed the view of

26"Indeed, to choose safety and profit and leave danger and trouble, this is human nature." [36]

27 "Their minds are well disposed to act for each other because they cherish self-seeking motives respectively. Therefore, when men deal with each other in managing affairs and rendering services, if their motive is hope for gain, then even with a native from Yüeh, it will be easy to remain harmonious. If the motive is fear of harm, then even father and son will become estranged and show resentment toward each other." [36]

${ }^{28}$ "The people are such as would be firmly obedient to authority, but are rarely able to appreciate righteousness." [36] 
"adapting the nature" from Daoism, while Laozi believes that the moral principles are the destruction of human nature. Thus, Han Feizi argued that only favors and punishments can shape people's behaviours, which follow their human nature. If people acted what social desires, then favors should be placed in order to encourage people to follow suit; If people behave against what the social desires, punishments should be exerted to prohibit people to do so. As long as human nature is "pursue interests and avoid dangers" and "cherish self-seeking", they can be shaped as the individuals that the society desire.

\subsection{Favours and Punishments: The Two Means of Political Rule}

Since human nature is "pursue interests and avoid dangers", Han Feizi believe the only effective way to govern the country is rule by law, which refers to the employment of favours and punishments ${ }^{29}$. What behaviours do the rulers favour and what are not should state in the laws, while the rulers control people through two means: favours and punishments. Social order can only be achieve when laws are clear, but not the employment of rituals ${ }^{30}$. Moreover, Han Feizi also proposes rulers to educated citizens by laws. As law clearly provided an objective guideline of behaviours, people should be educated by it. Therefore, social norms would form according to the laws and extended around the society. Once laws become a social norm, people would educate their descendants automatically. Finally, from Han Feizi's perspective of "abolish penalties by means of penalties", no laws, favours and punishments would be needed ${ }^{31}$.

\section{Comparative Philosophies: Mencius, Xunzi and Han Feizi on Human Nature and Political Governance}

After the above scrutinization of the first-hand literatures and the interpretations of the current academic publications, it generated a comprehensive understanding of the main principles among the three ancient Chinese thinkers on human nature and political governance. Thus, several significant aspects can be compared and contrasted.

\subsection{On human Nature and Social Impacts}

With regard to the discussions on human nature, three of them basically uphold dissimilar perspectives. Mencius formed his convictions that human own innate

\footnotetext{
29"The enlightened ruler controls his ministers by means of two handles alone. The two handles are punishment and favor. What I do mean by punishment and favor? To inflict mutilation and death on men is called punishment; to bestow honor and rewards is called favor. Those who act as ministers fear the penalties and hope to profit by the rewards. Hence, if the ruler wields his punishments and favors, the ministers will fear his sternness and flock to receive his benefits." [36]

30"If laws are clear, at home there will be no worry about any emergency or disturbance; if plans are right, there will be no disaster of either death or captivity abroad. Therefore, what preserves the state is not benevolence and righteousness." [36]

31 "In inflicting penalties light offences should be punished severely; if light offences do not appear, heavy offences will not come. This is said to be to abolish penalties by means of penalties. And the state will certainly become strong. If crimes are serious but penalties are light, light penalties breed further troubles. This is said to create penalties through penalties, and such a state will infallibly be dismembered." [36]
} 
cardinal virtues from his observations that individuals' good deeds do not originate from the considerations of personal interests, but the inborn care and concern to his/her fellows. Yet, Xunzi's views completely against Mencius's. Xunzi argued the main point behind the explicit good deeds is the abnegation of self-evil. The demonstrations of ethics are exclusively the external self, while the inner self or genuine human instincts of human beings filled with lusts and desires, which, in Xunzi's perspective, are iniquitous. The major difference between Mencius and Xunzi is the former focused on external actions, while the latter accentuated the internal character oneself. Although the society was, in Han Feizi's eyes, rife with immoralities, he did not share the same page with Xunzi. Indeed, he held a neutral view and argued that human beings are self-interest creatures that favor personal benefits and dread perils. What distinguished Han Feizi from the other two thinkers is he did not comment on human nature. In a similar vein, their views on how society influenced individuals' instinct are distinct from each other's. Mencius views society as a realm that allures people to abandon self-moral cultivation as there were too many immoral temptations. In contrast, Xunzi espoused society is an area that compels people to act morally by introduce sages as people's role models and adopted their principles as social guidelines and norms. Han Feizi thought society is a place of an exemplification of human inner self, which he did not conceive society served any functions to change people's internal senses.

\subsection{On Political Practices and their Functions}

Since their theories on basic human nature and society are nonidentical, it is not surprising that they advocated different political ideologies. Mencius promoted the rule of rituals (Lǐzhì). Rulers should self-cultivate his moral characters and be the model to their citizens. He also needs to practice benevolence, which extends his moral characters to the entire society, as well as educates his people by moral principles and norms. This is, indeed, conducive to his citizens to cultivate their inner good characters as well. Xunzi partly concurred with Mencius's political philosophies. He argued merely relied on rituals is not adequate to maintain social order. He proposed laws should be employed concurrently with education. Therefore, the rules should utilize both as tools of governance. Laws should be used to restrain people's detestable acts, while rituals served to socialize his citizens to practice good deeds. Similar to Daoism, Han Feizi chose to “conformity to nature” (順應自然). As he deemed human's nature need not to or cannot be changed, he suggested rulers can achieve a social order by well-exploit the human's inherent characters. A set of transparent and comprehensive laws are the only essential implement for rulers to clearly define what sorts of the behaviours would be rewarded and punished. According to his definition of human's nature as "favour interests and benefits, and to abominate dangers", they would act according to the laws. Also, he asserted laws served the function of education. When laws become the social norms and guideline of the 
people, the ancestors would school their descendants, which the society can automatically educate itself. Thus, no laws would be needed eventually.

\section{Conclusion}

This paper examined the philosophical views on human nature and its relationship with the idea of political governance among Mencius, Xunzi and Han Feizi. From their philosophies and the relations among them, it can observe that how the debate on human nature in ancient Chinese history evolves during warring state period. This also offers a vital foundation for the historians and philosophical scholars to understand why Legalism and Confucianism would prevail during a chaotic and peaceful period respectively within the ancient Chinese history by comparing the different theories of the three main thoughts. Moreover, the arguments of the three great pre-Qin philosophers provided critical insights towards the domains of philosophy as well as inspiring many philosophers and rulers in later generation, such as Qin Shihuang and Han Wudi.

\section{Conflicts of Interest}

The author declares no conflicts of interest regarding the publication of this paper.

\section{References}

[1] Chin, A. (2007) The Authentic Confucius: A Life of Thought and Politics. Simon and Schuster, New York.

[2] Williams, J.N. (1988) Confucius, Mencius, and the Notion of True Succession. Philosophy East and West, 38, 157-171. https://doi.org/10.2307/1398698

https://ink.library.smu.edu.sg/cgi/viewcontent.cgi?article=1254\&context=soss_resea $\underline{\mathrm{rch}}$

[3] Confucius (1990) The Analects. https://docsplayer.com/81564673-Analects-of-confucius-論語.html

[4] Moran, P.E. (1993) Three Smaller Wisdom Books: Lao Zi’s Dao De Jing, the Great Learning (Da Xue), and the Doctrine of the Mean (Zhong Yong). University Press of America, Lanham, MD.

[5] Mencius (1992) The Book of Mencius. Charles E. Tuttle Company, Boston, MA.

[6] Peterson, W.J. (1979) The Grounds of Mencius' Argument. Philosophy East and West, 29, 307-321. https://doi.org/10.2307/1398934 https://www.jstor.org/stable/1398934?seq=1\#page_scan_tab_contents

[7] Bloom, I. (1994) Mencian Arguments on Human Nature (Jen-hsing). Philosophy East and West, 44, 19-53. https://doi.org/10.2307/1399803 https://www.jstor.org/stable/1399803?seq=1\#page_scan_tab_contents

[8] Kim, S. (2011) Confucian Constitutionalism: Mencius and Xunzi on Virtue, Ritual, and Royal Transmission. The Review of Politics, 73, 371-399. https://doi.org/10.1017/S003467051100341X https://www.cambridge.org/core/journals/review-of-politics/article/confucian-const itutional-

ism-mencius-and-xunzi-on-virtue-ritual-and-royal-transmission/A375B615C7DA8 A4E824F0CBA87C84773 
[9] Li, C. (2013) The Confucian Philosophy of Harmony. Routledge, New York. https://books.google.com.hk/books?id=jSXjAQAAQBAJ\&dq=Mencius+rule+by+rit uals\&source $=$ gbs_navlinks_s

[10] Yu Y.-S. (2008) Humanities and Rational China. Linking Publishing Company, Sin-Pak-Chhī, Taipei.

[11] Hutton, E.L. (2008) Han Feizi's Criticism of Confucianism and Its Implications for Virtue Ethics. Journal of Moral Philosophy, 5, 423-453. https://doi.org/10.1163/174552408X369745 https://hutton.philosophy.utah.edu/HFZ.pdf

[12] Guo, X. (2002) The Ideal Chinese Political Leader: A Historical and Cultural Perspective. Greenwood Publishing Group, Santa Barbara, CA.

https://books.google.com.hk/books?id=6vG-MROnr7IC\&dq=Xunzi+idea+of + politi cal+rule\&source $=$ gbs_navlinks_s

[13] Goldin, P.R. (2017) A Concise Companion to Confucius. John Wiley \& Sons, West Sussex, England. https://doi.org/10.1002/9781118783863

[14] Sato, M. (2003) The Confucian Quest for Order: The Origin and Formation of the Political Thought of Xunzi.

https://books.google.fr/books?id=FXJuJl5XTqAC\&printsec $=$ frontcover\&dq $=$ The $+\mathrm{C}$ onfu-

$\underline{\text { cian+Quest }+ \text { for }+ \text { Order\&hl=en\&sa }=\text { X\&ved=0ahUKEwi626vmmuThAhVFExoKH }}$

[15] Goldin, P.R. (1999) Rituals of the Way: The Philosophy of Xunzi. Open Court Publishing Company, Chicago, IL.

[16] Jo, J.E. (2012) Analysis of the Discourse on Music of the Lüshichunqiu Mainly in Comparison with the "Yuelun" Chapter of the Xunzi. Doctoral Dissertation, University of London, London. https://eprints.soas.ac.uk/13533/1/Jo_3332.pdf

[17] Xunzi (2014) Xunzi: The Complete Text. Princeton University Press, Princeton, NJ.

[18] Xu, Z. (2016) Natural Theology Reconfigured: Confucian Axiology and American Pragmatism. https://doi.org/10.4324/9781315597553 https://books.google.com.hk/books?id=N6fOCwAAQBAJ\&dq=Shang+Yang++hum $\underline{\text { ans+nature } \& \text { source }=g b s \_n a v l i n k s \_s}$

[19] Lao, S.-G. (2010) New History of Chinese Philosophy. San Min Book, Taipei.

[20] Mou, Z.-S. (1953) Xunxuedalue. Central Cultural Relics Agency, Taipei.

[21] Guo, M.-R. (2012) Shipipanshu. People’s Publishing House, Beijing.

[22] Cua, A.S. (2013) Encyclopedia of Chinese Philosophy. Routledge, New York. https://doi.org/10.4324/9780203953624

https://books.google.com.hk/books?id=yTv_AQAAQBAJ\&dq=Shen + Dao + Guan + Z

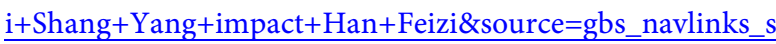

[23] Peerenboom, R.P. (1995) Law and Morality in Ancient China: The Silk Manuscripts of Huang-Lao. SUNY Press, New York.

https://books.google.com.hk/books?id=ctWt6bvFaNAC\&dq=Shen+Dao++humans $\underline{+ \text { nature\&source }=\text { gbs_navlinks_s }}$

[24] Rickett, W.A. (2001) Guanzi: Political, Economic, and Philosophical Essays from Early China, a Study and Translation, Volume 1. Cheng \& Tsui Company, Boston, MA.

[25] Xu, F.-G. (1969) History of Chinese Humanity-Pre-Qin. Joint Publishing, Shanghai.

[26] Wang, Z.-Y. (1991) Chinese Legalist Philosophy. Dongda Book Company, Taipei.

[27] Li, S.-P. (1998) Han Fei. Dongda Book Company, Taipei. 
[28] Wang, B.-X. (1993) Han Feizi’s Philosophy. Dongda Book Company, Taipei.

[29] Wei, Z.-T. (2009) History of Chinese Thoughts. Jilin Publishing Group Co., Ltd., Jilin.

[30] Goldin, P. (2012) Dao Companion to the Philosophy of Han Fei. Springer Science \& Business Media, London. https://doi.org/10.1007/978-94-007-4318-2

[31] Heisey, D.R. (2000) Chinese Perspectives in Rhetoric and Communication. https://books.google.com.hk/books?id=MRNIiD5vi44C\&pg=PA14\&dq=Han+Feizi +human+nature+social+observation \&hl=en\&sa $=X \& v e d=0$ ahUKEwjvqIjGgP7eAhU KZt4KHX3DBtsQ6AEINDAC\#v=onepage\&q=Han\%20Feizi\%20human\%20natur\% 20social\%20observation $\& \mathrm{f}=$ false

[32] Black, A. (2016) A World History of Ancient Political Thought: Its Significance and Consequences. Oxford University Press, Oxford. https://doi.org/10.1093/acprof:oso/9780198790686.001.0001

[33] Bárcenas, A. (2012) Xunzi and Han Fei on Human Nature. International Philosophical Quarterly, 52, 135-148. https://doi.org/10.5840/ipq201252214 https://philarchive.org/archive/BRCXAHv1

[34] Fu, L.-L. (2007) "Not to Be Good and Evil"-Discussion on Han Fei's Theory of HUMAN nature. Philosophical Collection, 40, 79-96.

[35] Wu, Y. (2015) History of Chinese Philosophy. San Min Book, Taipei.

[36] Han, F.Z. (1939) The Complete Works of Han Fei Tzu. Arthur Probsthain, London. 